Int. J. Electrochem. Sci., 12 (2017) $6600-6610$

International Journal of

ELECTROCHEMICAL

SCIENCE

www.electrochemsci.org

\title{
Antioxidant and Antiradical Properties of Green Tea Extract Compounds
}

\author{
Anna Masek ${ }^{1, *}$, Ewa Chrzescijanska ${ }^{2}$, Malgorzata Latos ${ }^{1}$, Marian Zaborski ${ }^{1}$, Anna Podsędek ${ }^{3}$ \\ ${ }^{1}$ Technical University of Lodz, Institute of Polymer and Dye Technology, Faculty of Chemistry, 90- \\ 924 Lodz, ul. Stefanowskiego 12/16, Poland \\ ${ }^{2}$ Technical University of Lodz, Institute of General and Ecological Chemistry, Faculty of Chemistry, \\ 90-924 Lodz, ul. Zeromskiego 116, Poland \\ ${ }^{3}$ Institute of Technical Biochemistry, Faculty of Biotechnology and Food Sciences, Technical \\ University of Lodz', 90-924 Lodz, Stefanowskiego 4/10, Poland \\ *E-mail: anna.masek@p.lodz.pl
}

doi: $10.20964 / 2017.07 .06$

Received: 10 March 2017 / Accepted: 29 April 2017 / Published: 12 June 2017

Green tea is currently an area of intense scientific research because of its exceptional and effective actions in anticancer therapy. The aim of this research was to determine the antioxidant properties of polyphenols contained in green tea. Examined was the correlation between bioingredients of the product tested and the ability to scavenge free radicals and reduce them by chelating the variable metal ion. A range of innovative research technology combines HPLC with electrochemical (cyclic and differential pulse voltammetry) and spectrophotometric (ABTS, FRAP and DPPH assays) analysis to rate the potential oxidation-reduction components of green tea. Described is the dependence of the chemical structure on antioxidant properties. It was found that a high content of catechins and esters of the gallic-type had a powerful influence on the antiradical properties of the studied tea extract.

Keywords: Green tea; Electrochemical oxidation; UV-VIS; Antioxidant; ABTS, DPPH

\section{$\underline{\text { FULL TEXT }}$}

(C) 2017 The Authors. Published by ESG (www.electrochemsci.org). This article is an open access article distributed under the terms and conditions of the Creative Commons Attribution license (http://creativecommons.org/licenses/by/4.0/). 